\title{
UNITED STATES OF AMERICA - COPYRIGHT LAW
}

U S law different from most other countries

Principles of US law -

dual system
61. The copyright law of the United States does not conform in certain respects to the requirements of the Berne Convention; hence it differs from the laws of all the member countries of that Convention. Indeed, in practice it differs in certain respects from the copyright laws of most countries including those which belong only to the Universal Copyright Convention. Save only in a handful of cases, the US copyright law has not served as a model for the copyright legislation of developing countries. However, because the United States is such a large market for cultural works, whatever their origin, it may be helpful to authors and others concerned with the creation and commercial promotion of cultural works in developing countries to have a brief summary of the salient features of US copyright law, in particular the requirements for securing protection in the USA for foreign works.

62. The present US copyright law is the Copyright Act, 1976 which came into force in January 1978. To understand its effect it is necessary to summarise briefly the law prevailing immediately prior to January 1978 . This is done in the following sub-paragraphs.

\section{Prior to 1 January 1978}

(a) There was a dual system. Unpublished works were protected by common law; published works were protected by 
Federal statute - the Copyright Act, 1909.

two statutory periods

registration and deposit

copyright indivisible (b) The duration of the protection of unpublished works at common law was indefinite. Published works were protected under the 1909 Act for a period of 28 years from the date of first publication, renewable for a second period of 28 years, provided certain conditions were strictly complied with.

(c) Copyright under the 1909 Act could not be enforced unless the work -

(i) had been published with a copyright notice, i.e. the symbol (C) accompanied by the name of the copyright owner and the year of publication. (NB, a work published without the copyright notice went into the pub1ic domain); and

(ii) had been registered and copies had been deposited with the Copyright office at washington in strict compliance with certain rules.

(d) Copyright under the 1909 Act was indivisible in the sense that, unlike the position in most other countries as explained in para. 36 above, a copyright owner could not assign simply one of the component rights within copyright to another person. He could issue a licence, even an exclusive licence, but he could not transfer total ownership of, for example, the reproduction right to one person and the broadcasting right to another so as to enable each of those transferees to enforce the rights they received by litigation in their own names. 
be "made"

in USA

public

performances

profit

cable TV -

no copyright

liability books must

must be for

(e) Subject to certain exceptions, copies of all printed books or periodicals in the English language were protected only if they had been "manufactured" in the United States.

(f) The right of a copyright owner to control the public performances of his works could only be exercised if the performances were given "for profit".

(g) Persons or enterprises which received "off air" programmes broadcast by radio and television broadcasters, and then transmitted those programmes by cable to members of the public, had no copyright liability either to the original broadcasters or to the copyright owners of the works incorporated in the programmes so transmitted.

\section{From 1 January 1978}

dual system abolished copyright only under 1976 Act

duration general mule life plus 50 years

special transition mules (a) The dual system of protection under both common law and statute has been abolished. Copyright subsists exclusively under the Copyright Act, 1976.

(b) The duration of copyright protection is now the life of the author plus 50 years. But special periods apply to works in existence on 1.1.1978 which enjoy protection under the new Act in accordance with special

transitional rules. These rules are:

(i) A work which on 1 January 1978 was within the first period of protection under the old law must have its copyright renewed within the last year of that first term - i.e. within the 28 th year from the year when it was first published. When 
indivisibility abolished

outhor has

right to

terminate

grants

registration

and deposit

miles relaxed this renewal is made the protection will extend under the 1976 Act for a further 47 years.

(ii) A work which on 1 January 1978 had al ready had its copyright renewed (i.e. was in its second renewal term) will have the duration of copyright automatically extended on the expiry of that renewal term. The total period of protection is therefore 75 years from the date of first publication.

(iii) A work unpublished on 1 January 1978 and protected at common law will automatically enjoy a further period of protection of 75 years.

(c) (i) Rights subsisting under the 1976 Act are no longer indivisible and component elements may be individually assigned.

(ii) An author - or after his death his heirs - may terminate any assignment or 1 icence executed after 1.1.1978. The right to terminate may be exercised during the five-year period following the first 35 years of the grant. In the case of publication rights, the fiveyear period starts 35 years from first publication or 40 years from execution of grant, whichever is earlier.

(d) Registration and deposit are still requirements of the new law. But in the case of foreign works failure to register and deposit does not debar a copyright owner from bringing legal proceedings to protect his rights. 
"manufacturing clause"

phased out

"for profit" requirement dropped

cable transmissions liable under special miles
He may, however, lose certain subsidiary benefits, such as the right to claim statutory damages and attorney's fees in an infringement action unless registration is made within 90 days of publication.

(e) The "manufacturing clause" (subpara (e) on page 8) is being phased out; it was originally intended that it would cease to operate from July 1982 but the cessation date has now been postponed for four years.

(f) The "for profit" requirement in the case of public performances has been abolished so that a copyright owner may exercise his public performance rights without having to prove that the performance in question was given "for profit".

(g) The cable transmission of a copyright work by the relaying of a broadcast programme containing the work imposes an obligation on the cable operator to pay royalties which are calculated under formulae of bewildering complexity administered and distributed by a statutory tribunal.
Copyright office
63. The US copyright law is administered by the Copyright office which is a Department of the Library of Congress in Washington DC 20559. The Copyright office has issued a series of leaflets explaining the principles of the law, the way in which it works in practice and the procedure for complying with the registration and deposit requirements. These pamphlets can be obtained on application to the Copyright office. 